1. まえがき

最近のコンピューター関連の技術雑誌をみての特 徵は AI (Artificial Intelligence: 人工知能), $\mathrm{KE}$ (Know-ledge Engineering: 知識工学) の汇濫である。 こうした新技術が燃焼工学の分野に取り入れられるの もそれほど遠い時期ではなかろら。燃焼機器の設計, 燃焼診断に $\mathrm{AI} ， \mathrm{KE} に$ 代表されるエキスパートシス テムを導入する前段階では広い意味でのデータベース が構築されていなければならない。本講座での液体の 燃焼の項でも説明されているように燃焼過程は複雑で あり, その一つ一つの過程の物理的ないしは化学的現 象を理解するうえで基礎となる燃焼速度，可燃限界， 火炎長, 火炎放射, 非燃焼·燃焼状態での流れの状態 などに加えて, 燃焼機器の評価に必要な火炎温度, 燃 焼効率, 燃焼負荷率, 排気ガス組成などの実験的デー タが重要視されている。そこで信頼性のある確度の高 いデータ值をどのようにして収集するかが課題となり 新しい測定法が登場してきている。

上記各項目についても多くの測定法が確立されてい るが研究室規模での測定法, 現場での測定法はおのず から限定されている。本稿では燃焼解析に必要な伝統 的な測定法については簡単に触れるにとどめ, 最近の 燃焼関連の新しい測定技術を紹介する。また，燃焼の 計測を取り扱う場合に燃焼現象を物理的・化学的に評 価する目的から燃焼そのものを対象として計測する場 合と, 炉制御のための燃焼計測との二つが考えられる がここでは前者に限定する。

\section{2. 燃焼関連の計測法の概要}

気体, 液体, 固体燃料の燃焼それぞれに固有の燃焼 計測と共通する燃焼計測とがあるが，ここでは後者に 重点を置く。また，工業炉のような連続的燃焼と内燃 機関での間欠燃焼とがありそれぞれに特色ある計測法 工学部 桐生市天神町 $1-5-1$
が確立されている場合もあるが，できうる限り共通の 計測法を記述するよらつとめたい。

燃焼場での測定対象として工業炉を例に燃焼計測項 目を大きく分外ると，

(1) 非然焼場の計測: 流れ模様の計測, 流量, 流速 の計測，噴霧計測，その他

(2) 燃焼場の計測: 火炎温度, 火炎形状, 燃焼速度, 燃焼効率, 反応物質濃度，火炎放射，熱流束， 燃焼騒音, その他

(3) 燃焼完結後の測定: 排気ガス組成, 微粒子, そ の他，のよらになろら。

\section{3. 燃焼の計測に要求される基本事項}

燃焼の計測に要求される基本事項を列挙すると,

(1) 時間的, 空間的分解能が高いこと,

(2) 実時間測定ができるかどらか，

(3) 同時多点測定が可能であることが望ましい，

（4)場の影響を受けにくいこと，

(5) 精度, 確度が高いこと,

(6) 個人差のない測定法であること，

などがあげられる。

こうした諸条件をできうる限り満足する測定法とな ると最新のエレクトロニクスを利用した高性能機器へ の指向となり，原理的に良く知られている物理現象を 高度に利用した光学的な測定機器の開発·研究, 応用 研究が活発となってきている21)。

\section{4. 基礎物理量の計測}

計測技術の原理は機械, 電気·磁気, 光学, 物理, 流体などのいずれかを利用している。流速，流量，温 度, 圧力, 化学種濃度の測定に際して伝統的に使用さ れている各種計測器類を表 1 にまとめた。これら機器 の選択に当たっては使用環境条件 (温度, 珐力, 雲囲 気ガスなど), 精度, 応答性, 分解能を十分に理解して 使用することは重要である。 
表 1 在来の主要な計測法

\begin{tabular}{|c|c|c|}
\hline $\begin{array}{l}\text { 流 } \\
\text { 速 }\end{array}$ & \multicolumn{2}{|c|}{$\begin{array}{l}\text { 圧式流速計, 翼車形流速計, 熱線 - 熱膜流速計, 超音波流速計, } \\
\text { 抵抗式流速計, 振動式流速計, 動電式流速計, 超音波流速計 }\end{array}$} \\
\hline $\begin{array}{l}\text { 流 } \\
\text { 量 }\end{array}$ & \multicolumn{2}{|c|}{$\begin{array}{l}\text { 差圧式流量計, 面積流量計, 容積流量計, 羽根車式流量計, 熱式流量計, } \\
\text { 超音波流量計, 電磁流量計, 質量流量計, 渦流量計, 層流式流量計 }\end{array}$} \\
\hline $\begin{array}{l}\text { 温 } \\
\text { 度 }\end{array}$ & \multicolumn{2}{|c|}{$\begin{array}{l}\text { 膨張温度計, バイメタル温度計, 熱電対温度計, 抵抗温度計, } \\
\text { サーミスタ温度計, 超音波気体温度計, 放射温度計, 光高温計, } \\
\text { 二色温度計, 光電管温度計, スペクトル反転法, }\end{array}$} \\
\hline $\begin{array}{l}\text { 圧 } \\
\text { 力 }\end{array}$ & \multicolumn{2}{|c|}{$\begin{array}{l}\text { 液柱形圧力計, 天秤式圧力計, 沈鐘式圧力計, 重錘式圧力計, } \\
\text { 弾性式圧力計, 電気式 (抵抗線式, 圧電式, 磁歪式) 圧力計, }\end{array}$} \\
\hline \multirow{2}{*}{$\begin{array}{l}\text { 化 } \\
\text { 学 } \\
\text { 種 } \\
\text { 濃 } \\
\text { 度 }\end{array}$} & 機器分析 & $\begin{array}{l}\text { ガスクロマトグラフ分析法 (TCD, FID ), 赤外線吸収法, } \\
\text { 質量分析計, 溶液遵電率法, 定電位電解法, 紫外蛍光法, } \\
\text { 二次導関数分光法, 磁気式分析計 }\end{array}$ \\
\hline & 化学分析 & ヘンペル法, オルザット法, 滴定法, 検知管法 \\
\hline
\end{tabular}

表 2 流れの可視化法1)

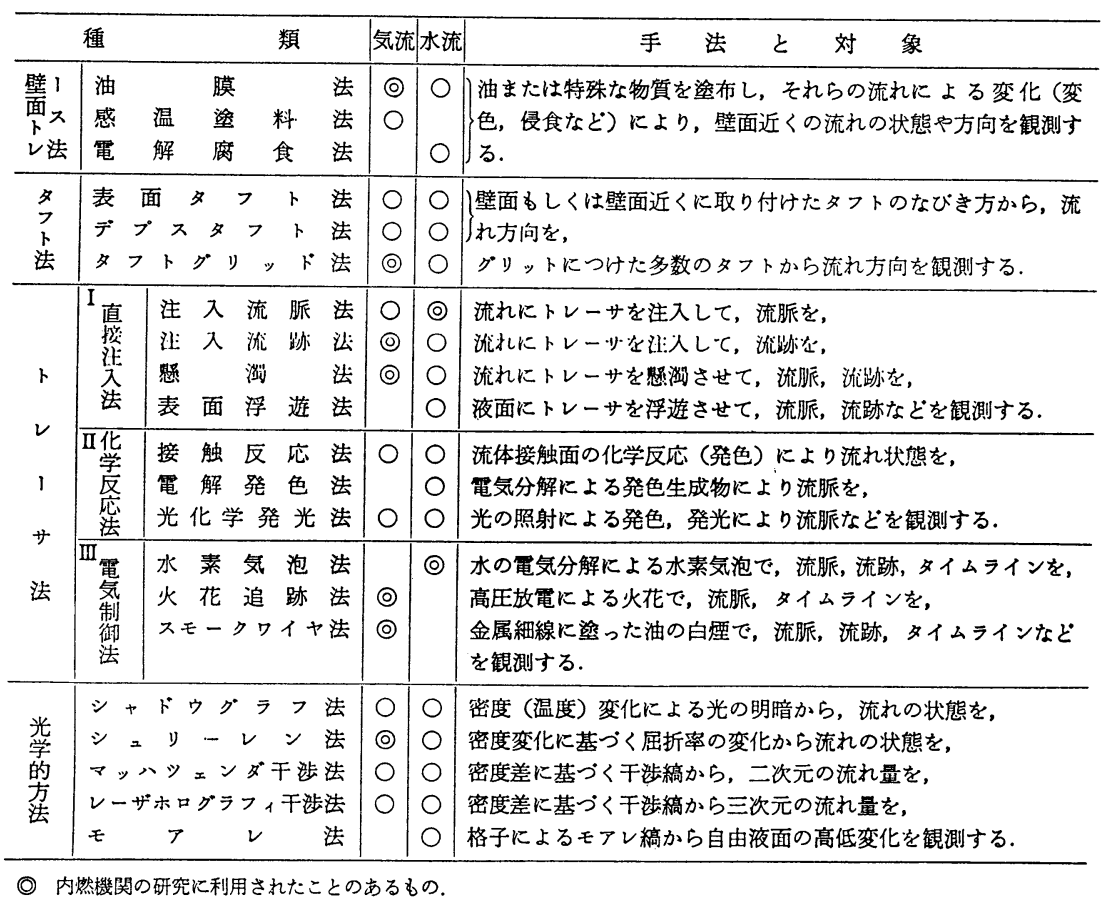

燃料の形態には気体, 液体, 固体のほかに COMp CWMのように混相状態の燃料もあり流量測定, 粒子 径測定などにさいしては細心の注意が必要である。

\section{5. 非燃焼場の計測}

燃焼機器の性能把握には燃焼場の情報で満足できる 場合が多いが, 機器の開発, 改善にかかわる場合には 非燃焼場での情報が理解を助けることが多い。流れ場
のフローパターン, 速度分布, 液体燃料の噴霧燃焼で は噴霧特性の把握などがそれに相当する。

5.1 流れ場の計測

燃焼機器の設計, 性能の把握にさいしては非然焼場 の流れ場, 燃焼場での流れ場のパターンを把握するこ とが重要となる場合が多い。流れ場の状態を知るには 可視化法の採用が一般的であり, 表 2 に代表的な手 
法1をまとめた例を示す。このらち尤も簡単で製作の 容易なタフト法を図 1 に示す。測定例は当講座“液体 の燃焼”編 (4 月号 p. 299図 6 参照)に示してある。逆 流の状態をも知ることができる。クシ状に製作すれば 多点同時観測ができる。非燃焼場での取得データが然 焼場を予測ないしはシミュレートできれば然焼機器の 開発, 改善に強力な手段となるが, 現時点では部分的 予測に利用される程度である。

流速の測定は表 1 に示したように数多くの測定法が 利用されているが，利用にさいしてはその特質を十分 に熟知していることが望ましい。流れ場の計測では平 均的な情報よりも局所情報を必要とすることが多く， ピト一管法, 熱線法, レーザ法が推奨できる。乱れ成 分の測定には熱線法あるいはレーザ法が適している。 三次元的情報を取得することもできる。

時間的·空間的分解能が高いことから基礎的研究に おいて最近急速に利用が進んでいる LDV (Laser Doppler Velocimeter) について触れておく。

音源が遠ざかるとその振動数が低くなり，近付くと 高くなるドップラー現象が知られている。光でもこれ が観察される。これを利用するのがLDVである。も つとも一般的な前方散乱差動型の光学系を図 2 に示す。 差動型はレーザ光を強度の等しい二つのビームに分け, これを測定点に交差させそこを通過するトレーサー粒 子からの散乱光の干渉を利用する。ドップラーシフト 周波数が散乱方向に無関係なため, 広い受光開口での 受光ができ，信号強度が強い。熱線法では逆流の計測 はむづかしが，LDVでは流速方向の判定ができる。

その判定には周波数シフタが用いられている。光に 周波数変移をかける方法としてはブラッグセル，回転 回折格子を用いる方法があるが，安定性，光強度の点 からブラッグセルが一般に用いられる。

単一粒子が測定体積を通過したとき，LDVからの 信号は図 3 に示される。（a ）は等しい強度の二つの ビームの交差部に形成される干渉じまの中心を縞間隔 に比べて十分小さな粒子が通過する理想的信号である。 （b ）は粒子が測定体積の中心を通過しているが，二つ のビームの強度が異なるか, 粒子径が縞間隔に比べて 大きくドップラー信号が小さくなっている。粒子が測 定体積の端を通過するとビームの交差していない部分, 交差部，交差していない部分と順次通過すると（c）の ように二つ山の信号となる。破線は粒子が測定体積を 通過したことを示す低周波成分であり，その上に高周 波のドップラー信号がのっている。この低周波成分を ペデスタルと呼ぶ。速度情報はドップラー信号に含ま

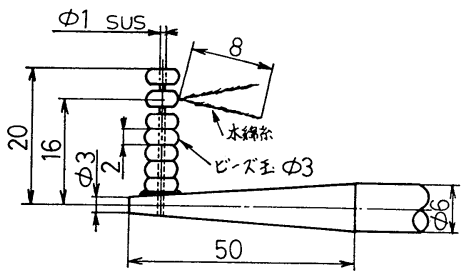

図1 ストリーマ

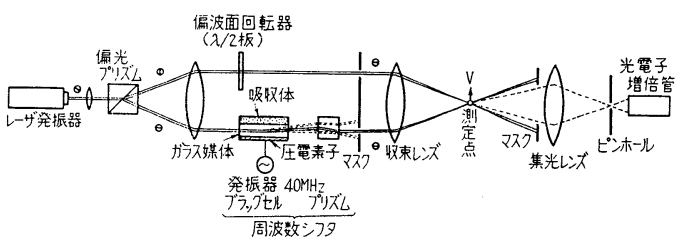

図 2 前方散乱差動形法の例2)

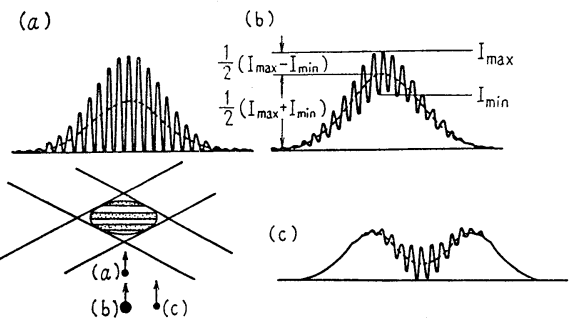

図 3 単一粒子からの信号2)

れており，ペデスタルに対するドップラー信号の比は ビジビリティと言い,

$\mathrm{V}=\left(\mathrm{I}_{\max }-\mathrm{I}_{\min }\right) /\left(\mathrm{I}_{\max }+\mathrm{I}_{\min }\right)$

で定義され，信号の質の評価に利用される。

ドップラー信号は一般に間欠的であり振幅，周波数 とも変化する。平均流速, 実時間流速変動, 乱れの強 さ $(\mathrm{rms})$, 乱れのエネルギースペクトルなどが測定可 能であるが適切な信号を得るにはシーディン゙グ粒子の 選定と供給法が成否を左右し, 加えて信号処理器の選 択が重要である。表 3 におむなシーディング粒子2)を, 表 4 に代表的な信号処理方法の比較 ${ }^{2)}$ 示す。詳細は 文献 2 に詳しい。最近，ファイバーを用いたLDVが 市販され圧力場での測定例が報告されるようになって きている。

\section{2 噴霧特性の測定}

液体燃料の燃焼は多くの場合噴霧燃焼の形態をとつ ている。噴霧特性により燃焼状態は影響を受けること は“液体の燃焼”で示された。燃料噴霧の形成過程は複 雑でありその特性を予測することは難しい。このため 燃焼に深く関与する燃料噴射ノズルの設計，改善に利 
表 3 シーディング粒子の例2)

\begin{tabular}{|c|c|c|c|c|}
\hline 発生法 & 粒 子 の 材 料 & 比重 & 粒径 $\mu \mathrm{m}$ & 備 \\
\hline $\begin{array}{l}\text { 液 } \\
\text { 体 } \\
\text { の } \\
\text { 霧 } \\
\text { 化 }\end{array}$ & $\begin{array}{l}\text { 水 } \\
\text { シリコンオイル } \\
\text { DOP または } \\
\text { ステアリン酸 } \\
\text { ボリェステルグリコール } \\
\text { ドライアイス+水 }\end{array}$ & $\left.\begin{array}{l}1 \\
0.97 \\
0.98 \\
0.85\end{array}\right\}$ & $\begin{array}{l}\left\{\begin{array}{l}\sim 10 \\
1 \sim 2\end{array}\right. \\
2 \sim 3 \\
0.3 \\
0.8\end{array}$ & $\begin{array}{l}\text { 超音波加湿器 } \\
\text { 蒸発抑制剤添加 } \\
\text { アトマイザ } \\
\text { JIS } 13 \text { 種 (熱凝縮) } \\
\text { JIS } 14 \text { 種 (フトマイザ) } \\
\text { \}大量発生 (舞台効果用) }\end{array}$ \\
\hline $\begin{array}{l}\text { 粉 } \\
\text { 体 } \\
\text { の } \\
\text { 流 } \\
\text { 動 } \\
\text { 化 }\end{array}$ & $\begin{array}{l}\text { 関東ローム } \\
\text { タルク (滑石) } \\
\text { フライフッシュ } \\
\text { カーボンブラック } \\
\text { 酸化チタン }\left(\mathrm{TiO}_{2}\right) \\
\text { フルミナ }\left(\mathrm{Al}_{2} \mathrm{O}_{3}\right) \\
\text { 窒化はう素 }(\mathrm{BN}) \\
\text { ポリスチレン } \\
\mathrm{NaCl}\end{array}$ & $\begin{array}{l}\sim 3.0 \\
\sim 2.8 \\
\sim 2.2 \\
\sim 1.8 \\
3.9 \\
4.0 \\
2.7 \\
1.02 \\
2.2\end{array}$ & $\begin{array}{l}8,2 \\
7, \quad 4.2 \\
5.1 \\
0.03 \sim 0.2 \\
0.25 \sim 2 \\
0.05,0.3,1 \\
<5 \\
0.09 \sim \text { 各種 } \\
1\end{array}$ & $\begin{array}{l}\text { JIS } 8 \text { 種, } 11 \text { 種 } \\
\text { JIS } 4 \text { 種, } 9 \text { 種 } \\
\text { JIS } 10 \text { 種 } \\
\text { JIS } 12 \text { 種 } \\
\text { 顔 料 } \\
\text { 研磨剤 (ニニオンカーバイト) } \\
\text { 固体潤滑剤 (電気化学工業) } \\
\text { 粒子, けん濁液 (ダウ,シェル) } \\
\text { 水溶液の蒸発 }\end{array}$ \\
\hline $\begin{array}{l}\text { 燃焼 } \\
\text { 生成物 }\end{array}$ & $\begin{array}{l}\text { たばこ, 線香 } \\
\text { バルサン甡煙香 } \\
\text { 酸化マグネシウム } \\
\end{array}$ & $\sim 3.6$ & $\begin{array}{l}0.1 \sim 1 \\
\sim 0.4\end{array}$ & $\begin{array}{l}\text { 污れる (やに) } \\
\text { 中外製薬 }\end{array}$ \\
\hline $\begin{array}{l}\text { 华 } \\
\text { 学 } \\
\text { 応 }\end{array}$ & $\begin{array}{l}\text { 四塩化チタン+湿り空気 } \\
\text { 塩化第二すず+湿り空気 } \\
\text { アンモニア+塩化水素 }\end{array}$ & & $\sim 1.2$ & $\left\{\begin{array}{l}\text { 測定部近くで発生させる } \\
\text { (腐食性あり) }\end{array}\right.$ \\
\hline
\end{tabular}

表 4 LDV 信号処理方法とその比較2)

\begin{tabular}{|c|c|c|c|c|}
\hline $\begin{array}{l}\text { 信号処理方法 } \\
\text { 测定条件・要求 }\end{array}$ & $\begin{array}{l}\text { 信号の } \\
S / N \\
\text { が悪い } \\
\end{array}$ & $\begin{array}{l}\text { 信号密度 } \\
\text { が低い }\end{array}$ & $\begin{array}{l}\text { 時 閔 } \\
\text { 分解能 }\end{array}$ & 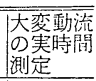 \\
\hline (1) スペクトラムアナライザ & 000 & 000 & $x$ & $\times$ \\
\hline （2）波形記憶 $+\mathrm{FFT}$ & 000 & 0 & 00 & $x$ \\
\hline (3) 光電子相関法 & 00 & 000 & 00 & 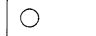 \\
\hline (4) フィルターバンク & 00 & ○ & Or & 00 \\
\hline 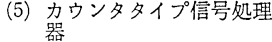 & 00 & 000 & 000 & ○ \\
\hline (6) 售波数トラッカ & 00 & $O$ & 000 & 00 \\
\hline
\end{tabular}

用できるデータは少なく，多くは実測結果を頼りにし ている。したがって噴霧特性の把握が重要な課題とな っている。

噴霧特性情報としては3),

(1) 平均粒子径 (mean diameter)

(2) 粒度分布 (distribution of drop size)

(3) 分散度 (degree of dispersion)

(4) 分布度 (degree of distribution)

(5) 貫通度 (degree of penetration)

などが重要であるが，間欠的噴霧ノズルの場合には噴 射度 (injection rate) が加わる。このほか噴霧角, 流 量係数も計測対象となるが，基本となるのは粒子径情 報である。

粒子径の測定法として,
(1) 痕跡法: $\mathrm{MgO}$ をガラス板に塗布し粒子を受け 止める。

(2) 液浸法:シリコンオイル等をガラス板に塗布し， 粒子を受计止める。

(3) 沈降法:粒子の気相中の降下時間を利用。

(4) 固化法:噴射液を固化させる。

(5) 直接写真撮影法

(6) 光学的測定法: 光吸収, 光散乱, 光回折, ホ口 グラフィ

などが利用されているが, 無数に近い数 $\mu \mathrm{m}$ から数百 $\mu \mathrm{m}$ 程度の微細粒子の計測であるためいずれの測定方 法にも一長一短がある。それぞれの詳細については紙 数の制約から割愛するが，さらに詳しく知りたい読者 は文献 (4)（5）を参照されたい。

非接触, リアルタイム測定の可能性のあるのは光学 的手法であり，中でもレーザを光源とする先に示した LDVを利用するものと回折法が有望である。最近注 目されているのは回折法である。

レーザ回折法による粉体微粒子径の測定器は数社か ら市販され広く利用されてきたが，液相中の固体粒子 に限られ，燃料噴霧のよらに気相中を飛しょらする粒 子群の計測が可能となったのはごく最近のことである。

物理学の教科書に書かれているように, 光路中にス リットやディスク(円艋)が置かれると回折模様が無限 


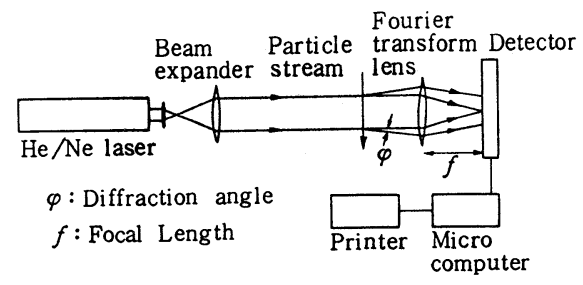

図 4 レーザ回折による粒子径測定システム

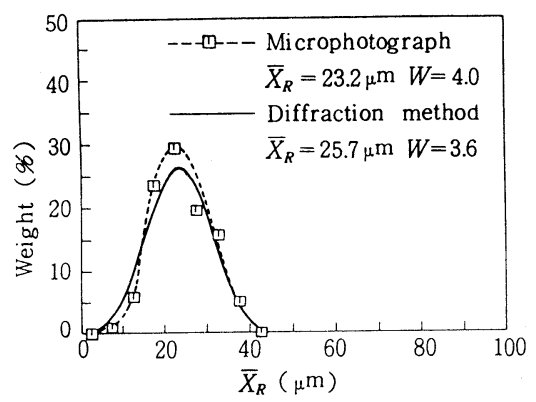

図 5 顕微鏡撮影による実測値と回折手法による 計測値との比較

遠方で観察される。適当なレンズを使用することによ ってその焦点面にこれを観察するよらに工夫している。 この手法は粒子形状は円形であるとし, 粒子群の個々 の粒子径を測定するのではなく粒子群全体からの回折 エネルギー分布を測定し，これと粒子径分布式(たと えば棚沢-抜山の式，Rosin-Rammlerの式など）とを 対応させることによって代表粒子径や分布指数を求め る6)7)。したがって個々の粒子径の個数, 最大粒子径な どの絶対值は測定できないことを留意すべきである。

代表的なシステム(英国マルバーン社2600)を図 4 に 示す。ガラスビーズを気相中で測定したものと顕微鏡 撮影した写真より測定したものとの対比を図 5 に示す が，よい対応をしているのがわかる。高温雲囲気場8), 圧力雲囲気場 (高圧 ${ }^{9)}$ ，低圧)でも測定ができる。ただ 高濃度場では多重回折が測定值に影響するが，補正法 が検討されており信頼性，確度には問題は少ない。デ ィーゼル噴射ノズルのような間欠的噴霧10)であっても リアルタイム測定が可能となってきている。

\section{6. 燃焼場における計測}

より高度の情報を的確に得るには，燃焼場での計測 が必要となることはいらまでもない。燃焼のモデリン グが進み, 燃焼場の予測が可能となると様々な燃焼場 での計測值が検証のために重要となり，流速，温度， 化学種濃度, 粒子径なども精度の高い局所情報が要求 されることとなろら。

\section{1 燃焼場における流れの測定}

実用燃焼機器の多くは燃焼用空気に旋回を与え, 燃 料と混合させながら燃焼させる旋回火炎の形態を取っ ている。そのような火炎の安定性, 燃焼特性, 反応化 学種濃度さらには排出物質濃度を知り, 燃焼の改善, 然焼機器の改善を行らためには旋回流やそれに誘起さ れる逆流域の形成状態, 流動状態, 燃料との混合過程, 燃焼過程を知り火炎構造を把握する必要がある。

燃焼場で測定が可能な測定法は先に紹介したLDV であり測定例 ${ }^{11)}$ が報告されているが，ガス火炎に限ら れる。火炎内の測定では火炎面での屈折率の変化があ り 2 本のレーザ光線の交差部での干渉縞が動くことが 指摘されており と呼んでいるが，これによる誤差要因を注意する必要 がある。

6.2 火炎構造の可視化

燃焼場の流体的状態を可視化する技術は未完成であ り，粒子軌跡法など種々の試みが為されているが層流 火炎に限定され, 乱流火炎では完成した手法はまだ見 当たらない。ここでは筆者らが試みているCT (Computer Tomography) 法と画像解析法の組み合せによ る可視化技法を示す13)。

CT は医学の診断分野, 材料の非破壊検査分野では 広く利用されているが, 燃焼場での研究は緒についた ところである。赤外検出素子の高性能化, $\mathrm{CCD}$ (電荷 結合素子) カメラの高密度化などによってセンサーと しての性能が向上したこととコンピューター機器の高 性能化 (高演算速度, 高密度メモリ一化, $\mathrm{AD}$ 変換器 の高性能化)や低価格化によって実現可能となったも ので今後改良, 高性能化が期待される新技術である。

CT 手法の詳細は専門書 ${ }^{14)}$ に譲り, 結果のみを示す。 火炎の輝度を利用しての火炎構造の可視化例を紹介し ておく。測定システムの一例を図 6 に示す。 2 組みの ブンゼン火炎を並べバーナーを 360 度回転させること

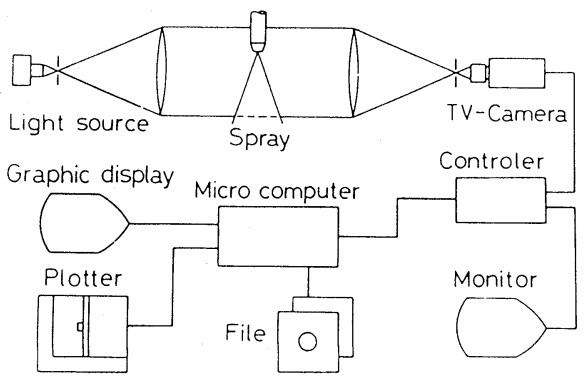

図 6 試作CT装置 


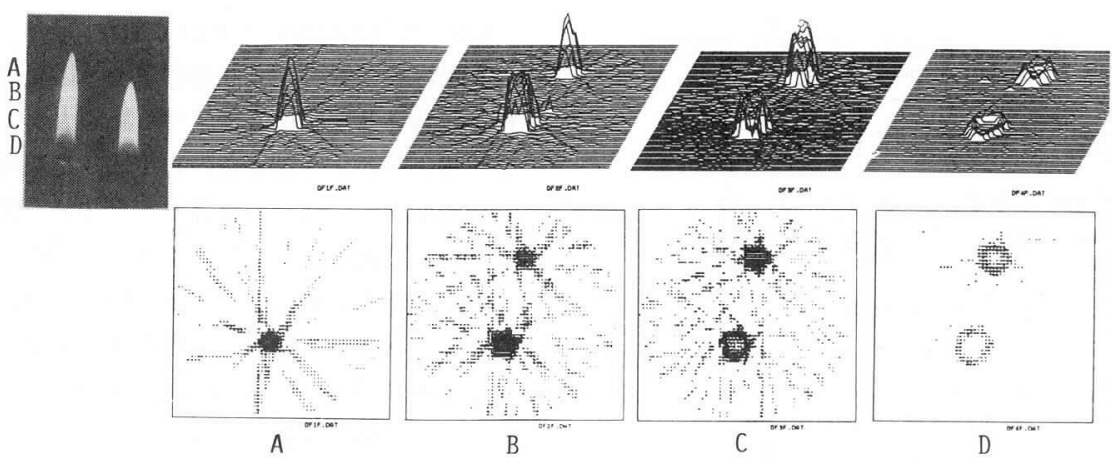

図 7 Dual burner利用の再構成画像, および断面情報

によってデータサンプリングを行い図 7 に示す燃焼火 炎の最構成画像を得ている。

同様の手法で熱線を利用した温度分布の可視化 ${ }^{15)}$, 燃焼反応の可視化が試みられている16)。乱流火炎での $\mathrm{OH}$ ラジカルをパルスレーザ蛍光法により得て濃度分 布の可視化例17)があり，また， CCDカィラを利用し ての $\mathrm{OH}, \mathrm{CH}$ ラジカルの発光強度分布 ${ }^{18)}$ が示されて いる。

\section{3 燃焼場での温度計測}

温度計測法は表 1 に示したよ5にいくつかの方法が あるが，燃焼場に適応できるものは熱電対法，光高温 度計, 放射温度計であり, 最近では非接触に加えて他 の測定要素(たとえば化学種濃度) との同時計測の要求 からここでもレーザ利用の開発が進んでいる21)。

然焼場での温度計測は易しいようで難しい。最も一 般的な熱電対を利用する場合を見てみよら。熱電対を 用いるとさ感温部を裸線のまま使用する場合と, 素線 を腐食，摩耗などから保護するためにシース線を用い たり保護管に挿入したりする場合がある。とくに注意 を必要とするのは測定場に反応性化学種が存在する場 合で感温部での触媒反応による反応熱の吸・放出によ る測定䛊差が避けられないことである。また変動温度 を測定したいような場合には, 熱容量のために応答に 一時遅れが生ずるので電気回路により補償する必要が ある。さらにンース線の場合や保護管使用の場合は, とくに熱伝導損失により感温部は真温度とはならず補 正が必要となるので注意が必要である19)。熱電対挿入 による流れ場の変動, 燃焼状態の変化も観察される。

触媒作用による計測温度の違いは反応帯に近い部分 では数百度にもなる場合がある。これを防ぐには感温 部をコーティングするのがよい。筆者らはHexamethyl disiloxane $\left\{\left(\left(\mathrm{CH}_{3}\right)_{3} \mathrm{Si}\right)_{2} \mathrm{O}\right\}$ による $\mathrm{Si}$ コーテ ィングを行っている20)。さらに精度をあげるには等速
吸引法の併用も有効である。

ふく射温度計も工業的に広く利用されている測定法 である。使用に際して留意すべきことはセンサー(検 知素子) の波長特性, 応答特性, 干渉ガス成分による 測定誤差の有無などである。ファイバーを利用したふ く射温度計も実用化されており，七ンサーの高性能化 と相まって今後ますます高範用に使用されるものと予 測される。

局所然焼温度に近い温度がえられる計測法として赤 外線放射温度計測法がある。これは燃焼がス成分の $\mathrm{H}_{2} \mathrm{O}, \mathrm{CO}_{2}, \mathrm{CO}, \mathrm{HC}$ な゙から放射される赤外線を 検出し, 温度を決定しょらとするものである。発光法 と吸収発光法とがある。発光法は被測定ガスの放射強 度より温度を測定するが被測定ガスの放射率を与える 必要がある。吸収発光法は基準黒体炉を用い, 透過率 と放射強度を同時に計測し温度を決定するもので被測 定ガスの放射率を必要としない利点がある。

レーザ光を用いる温度測定機器としてレーレー散乱 法, ラマン散乱法の研究·開発が進んでいる211。濃度成 分の同時計測ができることから実用化の期待は大きい が, 現時点では実験室段階の利用に留どまっている。 ラマン法の一つである CARS (Coherent Anti-Stokes Raman Spectroscopy) 法は内燃機関の燃焼解析に利 用される段階にきているものもあるが高価であるため 普及は遅々としている。

6.4 化学種濃度の計測

燃焼反応過程にある化学種, 排気ガス成分中の化学 種，未燃焼燃料の計測がこの項の対象となる。

実験室規模のバーナー火炎ではガスクロマトグラフ の利用が多いが, 実用規模の然焼研究ではNDIR (非 分散赤外方式: 各種ガス成分), NDUV (非分散紫外方 式: 窒素酸化物), $\operatorname{CLD}$ (化学発光方式: 窒素酸化物), $\mathrm{FID}$ (フレームイオン検出方式: 炭化水素)などの分析 
機器が使用されている。この外屈折率方式, オルザー ト方式も利用されている。

$\mathrm{NO}_{\mathrm{x}}$ 成分の測定は燃焼管理の上で重要であり，上 記のように測定原理の異なる分析法があるが，その特 徵比較を表 5 に示す。

レーザ利用の測定法としては, レーザ励起蛍光法
(LIF) が注目されている。上記ラマン法では高濃度化 学種の計測にたいして ppmオーダーの低濃度化学種 の測定ができる21)。

レーザを用いる測定機器は一般に高価であるが，従 来にない新しい知見が得られることから今後ますます 利用が拡大寸るものと予測される。

表 5 窒素酸化物分析法の比較 ${ }^{26)}$

\begin{tabular}{|c|c|c|c|c|c|}
\hline 項目 分析法 & 化学発光 法 & $\begin{array}{c}\text { 赤外線吸收法 } \\
\text { (非分散形赤外分析計) }\end{array}$ & 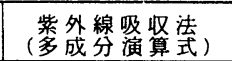 & $\begin{array}{c}\text { 紫外線吸収法 } \\
\text { (オゾン酸熱分解式) }\end{array}$ & 定電位電解法 \\
\hline 测定成分 $\left\{\begin{array}{l}\text { 直接 } \\
\text { 間接 }\end{array}\right.$ & $\begin{array}{l}\mathrm{NO} \\
\mathrm{NO}_{\mathrm{x}}\end{array}$ & $\begin{array}{l}\mathrm{NO} \\
\mathrm{NO}_{\mathrm{x}}\end{array}$ & $\mathrm{NO}, \mathrm{NO}_{2},\left(\mathrm{SO}_{2}\right)$ & $\begin{array}{l}\mathrm{NO}_{2} \\
\mathrm{NO}_{\mathrm{x}}\end{array}$ & $\mathrm{NO}_{\mathrm{x}}$ \\
\hline $\begin{array}{l}\text { 测 定 範 羿 } \\
(\mathrm{ppm})\end{array}$ & $\begin{array}{l}0 \sim 10 \text { から } \\
0 \sim 10000\end{array}$ & $\begin{array}{l}0 \sim 20 \text { から } \\
0 \sim 10000\end{array}$ & $0 \sim 10000$ & $0 \sim 10000$ & $\begin{array}{l}0 \sim 100 \text { から } \\
0 \sim 5000\end{array}$ \\
\hline 二 変換方式 & $\begin{array}{l}\mathrm{NO}_{2} \rightarrow \mathrm{NO} \\
\text { 還元形コンバータ }\end{array}$ & $\begin{array}{l}\mathrm{NO}_{2} \rightarrow \mathrm{NO} \\
\text { 還元形コンバータ }\end{array}$ & コンバータ不要 & 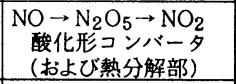 & コンバータ＼cjkstart不要 \\
\hline 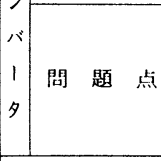 & 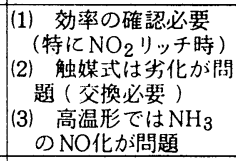 & 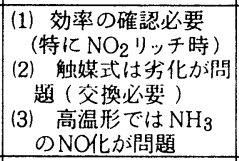 & (コンバータなし ) & 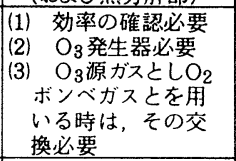 & (コンバータなし ) \\
\hline $\begin{array}{l}\text { 検出方式と } \\
\text { そ } \text { の保 守 }\end{array}$ & 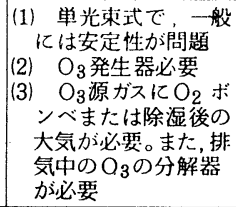 & (1) 袮光束式 & $\begin{array}{l}\text { (1) 被光束式 } \\
\text { 非破塤測定法 }\end{array}$ & (1) 二波長方式が多い & $\begin{array}{l}\text { (1) 絶対電流測定のた } \\
\text { め安定性か㵍題 } \\
\text { (2) 電解セルの交換が } \\
\text { 必要 }\end{array}$ \\
\hline 共存ガスの影響 & 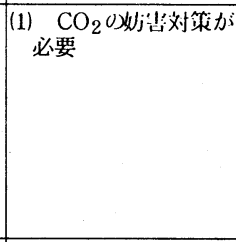 & (1) $\underset{\text { 害対策が必要 }}{\mathrm{CO}_{2}} \mathrm{CO}_{2} \mathrm{O}$ 奴 & $\begin{array}{c}\text { (1) 炎用上想祝できる } \\
\text { (2) 芳香族 HC があれ } \\
\text { は妨害を受ける }\end{array}$ & (1) 尖川上烸視できる & 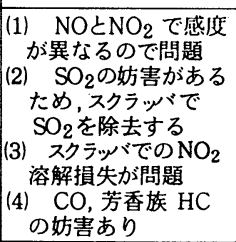 \\
\hline ゼロドリフト & 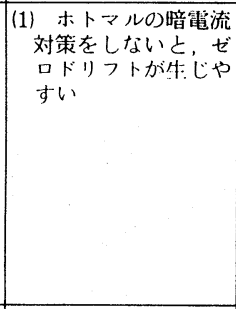 & 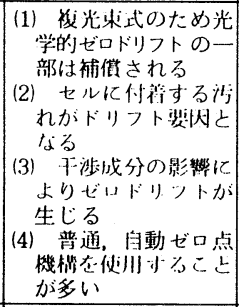 & 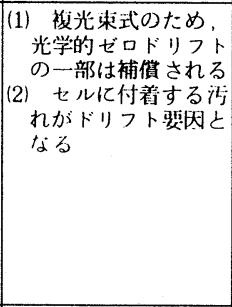 & 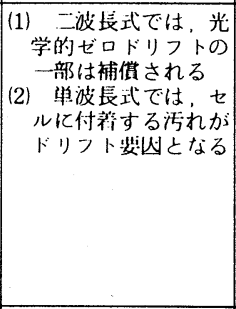 & $\begin{array}{l}\text { (1) 軍気的ドリフトの } \\
\text { 可能性がある }\end{array}$ \\
\hline スパンドリフト & $\begin{array}{l}\text { (1) } \text { ホトマルの感度変 } \\
\text { 化等電気的ドリフト } \\
\text { 加直接影響する } \\
\text { (2) 流量変動が影響 } \\
\text { (3) 普通自動不パン } \\
\text { 調整機構を使用する } \\
\text { ととが多い }\end{array}$ & $\begin{array}{c}\text { (1) スパンドリフトは } \\
\text { 大きくない }\end{array}$ & $\begin{array}{c}\text { (1) スパンドリフトは } \\
\text { 大きくない }\end{array}$ & \begin{tabular}{|c|} 
(1) スパソドリフトは \\
大きくない
\end{tabular} & $\begin{array}{l}\text { (1) 電気的性能变化が } \\
\text { 直接影笽するる。 } \\
\text { (2) 流量変動が影響 }\end{array}$ \\
\hline $\begin{array}{l}\text { サンプリング系 } \\
\text { の 問 題 点 }\end{array}$ & 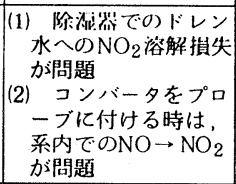 & 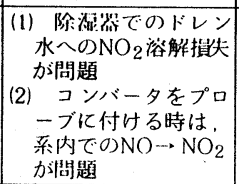 & $\begin{array}{l}\text { (1) 除酒器でのドレン } \\
\text { 水への } \mathrm{NO}_{2} \text { 溶解損 } \\
\text { 失か㵍題 }\end{array}$ & $\begin{array}{l}\text { (1) 除湿器でのトレン } \\
\text { 水への } \mathrm{NO}_{2} \text { 溶解損 } \\
\text { 失が問題 }\end{array}$ & $\begin{array}{l}\text { (1) スクラッバおよび } \\
\text { トレン水へのNO }{ }_{2} \text { 溶 } \\
\text { 解損失が問題 }\end{array}$ \\
\hline の & 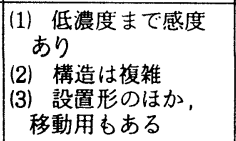 & $\begin{array}{l}\text { (1) 千涉成分のため, } \\
\text { 高感度ではない } \\
\text { (2) 構造は普通程度 } \\
\text { (3) 設置形が普通 }\end{array}$ & $\begin{array}{l}\text { (1) 感度は普通 } \\
\text { (2) 光学系·電気回路 } \\
\text { 系方複雑 } \\
\text { (3) 設置形が普通 }\end{array}$ & $\begin{array}{ll}\text { (1) } & \text { 感度は普通 } \\
(2) & \text { 構造は普通程度 } \\
\text { (3) } & \text { 設置形が普通 }\end{array}$ & $\begin{array}{ll}\text { (1) } & \text { 感度は普通 } \\
\text { (2) } & \text { 構造は簡単 } \\
\text { (3) } & \text { 移動形か普通 }\end{array}$ \\
\hline
\end{tabular}




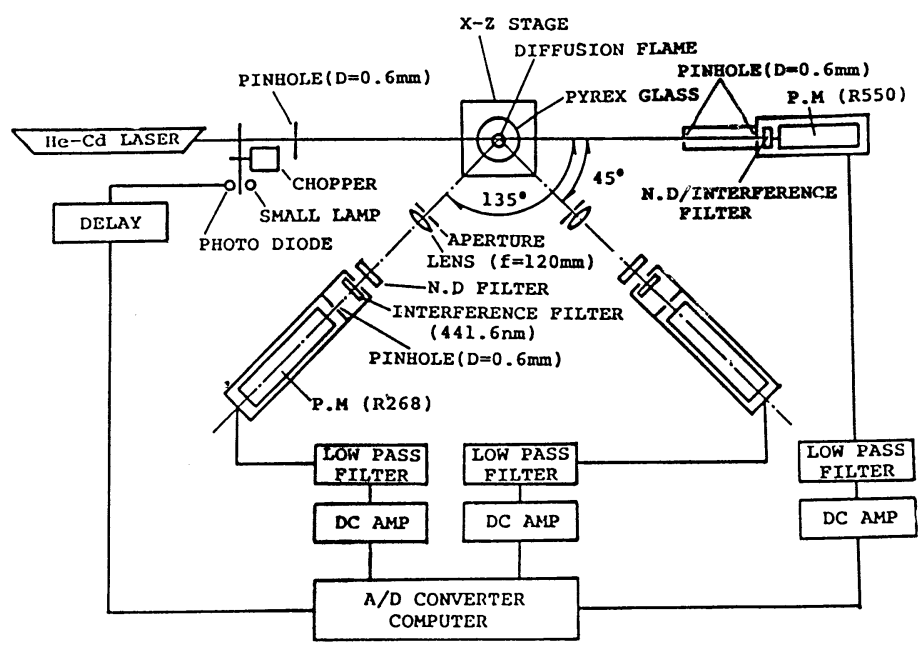

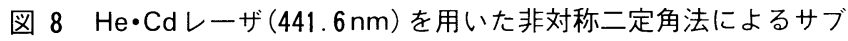

ミクロン粒子測定装置システム図

\section{5 スス粒子の測定}

重質液体燃料や固体燃料を燃焼する場合やディーゼ ルエンジンからの排出固体粒子の低減が大きな課題之 なっており，低減のための然焼機構の解明，後処理装 置の開発などの目的から濃度測定，粒子径測定につい ての関心が高い。

排出濃度の測定ではJISによる規定 (JIS Z 8808)が あるが，実験室での測定はフィルターを利用しての絶 対量科量による測定が多い。個々の粒子の観察は電子 顕微鏡，走査電子顕微鏡により，構造解析にはX線回 折などが用いられている。

スス粒子は数十 $\mathrm{nm}$ から数百 $\mathrm{nm}$ オーダーの微細粒 子であるため, 非接触, リアルタイム測定ではレーザ 光利用の独壇場でありミ一散乱法, レーレー散乱法が 中心となっている。使用レーザは $\mathrm{He}-\mathrm{Ne}$ (波長623.8 $\mathrm{nm}), \mathrm{Ar}($ 波長 $488.0 \mathrm{~nm}), \mathrm{He}-\mathrm{Cd}($ 波長 $441.6 \mathrm{~nm}$ ) などであるが，短波長レーザの利用が進んでいる。

ミ一散乱法による研究は国内·外で数多く実施され ているが，ここでは筆者らが試作したリアルタイム測

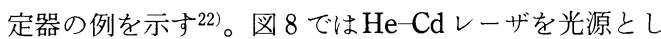
た 2 定角散乱法を採用し，散乱光強度比により粒子径 を算出している。ミ-散乱法では被測定物質の屈折率 を正しく評価する必要があるのが難点である。図 9 は 文献值に見られるスス物質の屈折率をパラメータに散 乱光強度比一粒子径の関係を示している。この測定器 による拡散火炎 (メタン一空気)内の粒子径一温度，数密 度一温度の測定例を図10に示す23)。

屈折率の影響をキャンセルする方法として，異なる

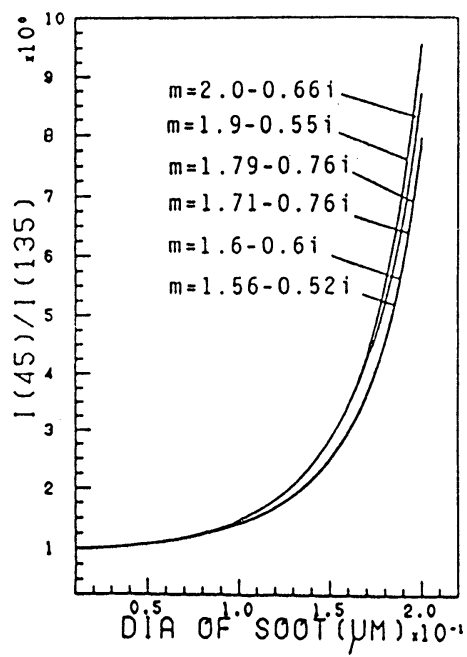

図 9 粒子径亡散乱光強度比の関係

2 波長のレーザを光源とする散乱法を採用する測定器 も開発24)されているが普及するには時間がかからら。

6.6 その他の計測

以上の計測の外，燃焼の基礎的情報である燃焼速度 計測，可燃限界計測，消炎距離計測などについては文 献 (25) に， また燃焼機器の特性把握に必要な熱放射計 測，燃焼騒音・振動計測，燃焼効率の計測などについ ては文献 $(26,27)$ に解説されている。

\section{7.あとがき}

与えられたタイトルの“燃焼の計測”を解説するには 紙数の制約が大きく，表面的解説になってしまったこ 


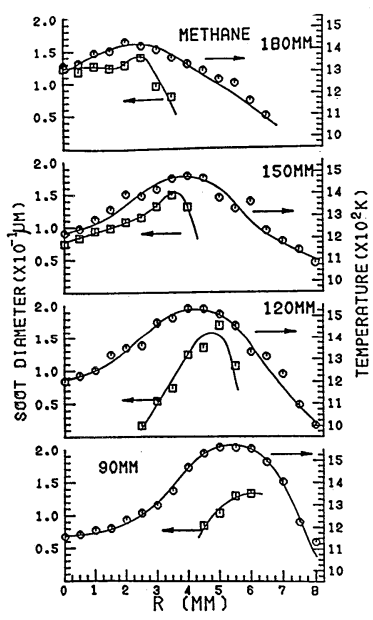

Soot粒子经一火炎温度の関係

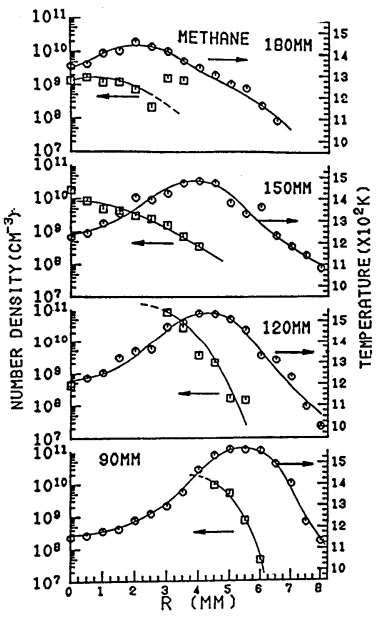

soot濊度一火炎温度の関係

図 10 すす粒子径・濃度の測定例

とを悔やんでいる。

研究室規模の然焼火炎ばかりではなく実用規模に近 い火炎での利用ができれば測定技術として確立し，普 及するものと思われるが，多くの測定技術は難しさを 秘めており期待に反することが多いのが現実である。

国内では文部省の資金援助のもとに大学の研究者を 中心にレーザ診断法の研究が実施され，その成果が最 近公刊されている(文献21)。また日本機械学会では研 究協力部会内に燃焼関連の分科会が設置され，第一線 で活踓中の産·官·学の研究者による研究協力が行われ ている。本稿でもその成果報告書の一部を引用してい るが，燃焼に関心ある読者には是非ご一読をいただき たい。ここで割愛した大部分が補われるものと思う。

なお引用文献は読者が容易に入手できる資料をえら んでいるので，多くを国内文献としたことをご承知い ただきたい。

\section{文献}

1) 自動車エンジンの排気浄化一燃料.燃焼·触媒一 $p$. 202(昭55) 文部省特定研究 “自動車の排気浄化に 関する基礎研究”成果編集委員会

2) 技術資料「流体計測法」，日本機械学会，p. 143 （昭60）

3）棚沢 泰，ディーゼル機関 1，（山海堂）p. 60 (昭36)

4）倉林俊雄，噴霧の計測（1）燃焼の計測に関する講 習会テキスト，(燃料協会)，p. 48（昭56.11）

5) 中山満茂，噴霧 ·粒子径の計測 燃焼装置の合理
的設計手法研究分科会報告書，（日 本機械学会）p. 352 (昭57.9)

6) Swithenbank, J., et al., AIAA paper 76-69 (1981)

7）中山満茂，表面，22，27（1984）

8）中山満茂, 荻原五郎, 日本機械学会 論文集掲載予定

9) 中山満茂, 燃焼のレーザ計測とモデ リング,（日本機械学会） p. 367 (昭62)

10）中山満茂, “ディーゼル機関の燃料 噴霧と燃焼”（自動車技術会） p. 54 (昭60)

11) Takagi, T., et al., 20th Symp. (Intn) on Combustion The Combustion Institute, p. 251 (1984)

12) Hong, N. S., Proc. R. Soc. Lond. A 353, p. 77 (1977)

13）中山満茂，燃焼研究，No. 71，p. 31（1986）

14）岩井喜典編, CTスキャナ(コロナ社) (昭56)

15）内野美洋，他，第24回燃焼シンポジウム， p. 19 (昭61)

16) Emmerman, P. J., et al., J. Energy, 4-2, p. 70 (1980)

17) Kychakoff, G., et al., Appl.Opt., 23-5, p. 704 (1984)

18）水谷幸夫，他，日機論， 52-476 B，p. 1931（昭 61)

19) 大竹一友，日本ガスタービン学会誌，11-41， p. 2 （昭58）

20）鈴木富雄，他，機論，48-434， p. 2116（昭57）

21）燃焼のレーザ計測とモデリング，日本機械学会 （昭62.3）

22）中山満茂，他，日本金属学会誌，24-7, p. 561 (昭60)

23）中山満茂，他，第23回燃焼シンポジウム， p. 334 （昭60）

24）西田修身，他，内燃機関，25-324，p. 19（昭61）

25) Gaydon, A. G., Flames Chapman \& Hall Ltd (1986)

26）燃焼装置の合理的設計手法研究分科会成果報告 書，日本機械学会（昭57）

27）連続燃焼装置の高効率・低公害設計技術研究分科 会成果報告書, 日本機械学会（昭60） 


\section{燃焼講座の終了にあたって}

会誌編集委員会

昨年来の急激な円高経済状態が続いている今日，石油製品は比較的安定した価格を維持している。この ためか省エネルギーの意欲はこのところ停滞気味の感が見られる。しかしながら 21 世紀を見込んだ場合に は化石然料はいずれひっ迫するものと予測されている。燃料の質が今後ますます粗悪化して行くと見たと き, 燃焼機器にはさまざまな燃料が供給されるよらになり, その要求に答えられる Flexible Fuel Combustorの開発が進行するものと予測される。このよらな時, 気体, 液体, 固体各燃料の燃焼機構を十分に 理解しておかねばならないであろら。また，新しいコンセプトに基ついて燃焼機器の試作·開発，改良を 実施するにはより精度の高い測定機器が必要となろら。そのような場合に本講座が些かでも役立つことが あればと願っている。

\section{液 体 微 粒 化 関 係資 料}

\section{污液体の微粒化に関する講演会＼cjkstart講演論文集（各テ共）}

第 6 回(昭52）3,000円，第 7 回（昭54），第 8 回（昭55），第 9 回(昭56）各 3,500円， 第10回（昭57） 4,000円，第11回（昭58）3,500円，第12回(昭59）4,000円 第13回（昭60）4,000円，第14回（昭61）4,000円

（第 1 回〜第 5 回分ご希望の場合は,コピー注文を承ります。）

々液体の微粒化に関する講習会 テキスト（昭51）２,000 円

公第 1 回液体微粒化国際会議（昭53）プロシーディングス 8,000円（干共）

扣問い合わせ・申し込み先; (社) 燃料協会

干101 東京都千代田区外神田6-5-4（偕楽ビル）

T E L $\quad 03-834-6456 \sim 8$

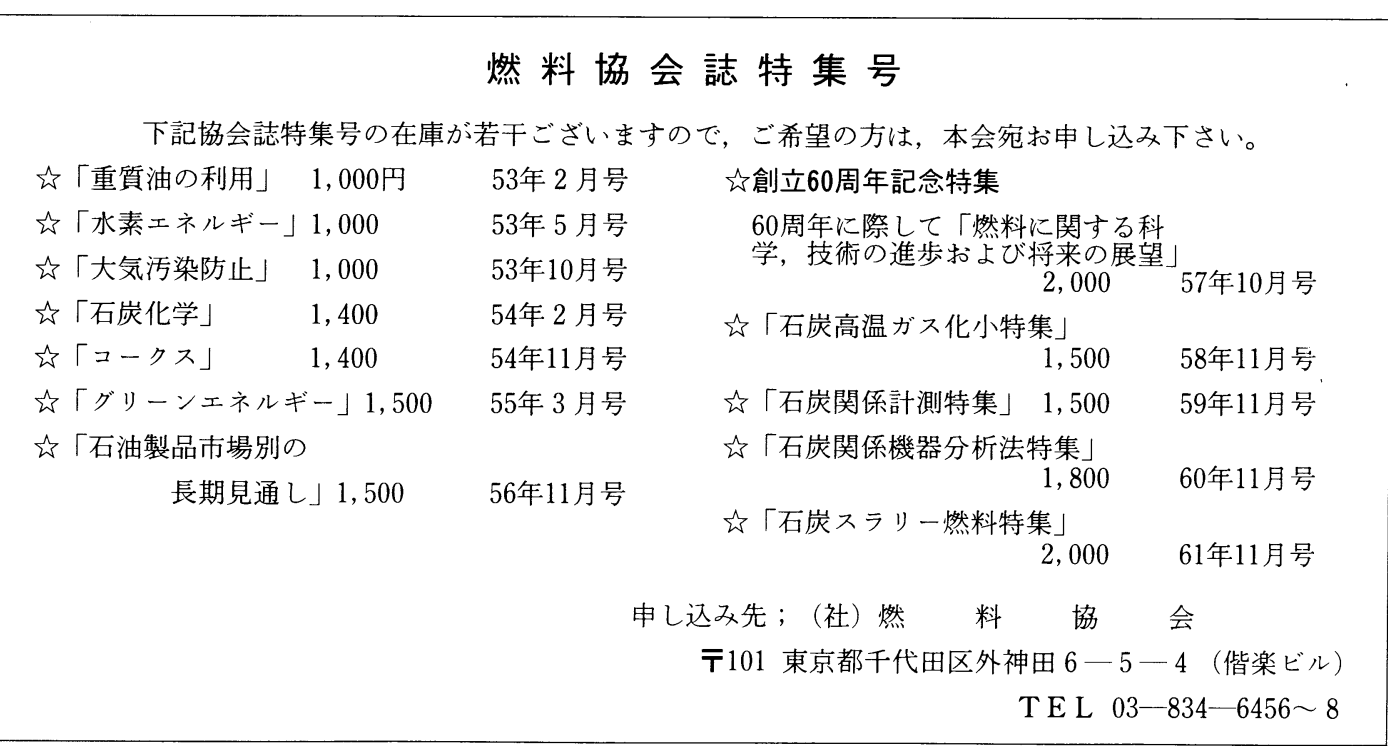

